\title{
Genetic analysis of residual feed intake adjusted for fat and carcass and performance traits in a Nellore herd
}

\author{
Giovanna Faria de Moraes $^{1}$ Luiza Rodrigues Alves Abreu ${ }^{2}$ \\ Isabel Cristina Ferreira $^{3}$ Idalmo Garcia Pereira ${ }^{4}$
}

\author{
'Programa de Pós-graduação em Ciências Veterinárias (PPGCV), Universidade Federal de Uberlândia (UFU), 38405-320, Uberlândia, MG, \\ Brasil. E-mail: g.f.moraes@hotmail.com. Corresponding author. \\ ${ }^{2}$ Programa de Pós-graduação em Zootecnia (PPGZ), Universidade Federal de Minas Gerais (UFMG), Belo Horizonte, MG, Brasil. \\ ${ }^{3}$ Embrapa Cerrados, Brasília, DF, Brasil. \\ ${ }^{4}$ Departamento de Zootecnia (DZO), Universidade Federal de Minas Gerais (UFMG), Belo Horizonte, MG, Brasil.
}

\begin{abstract}
The study of the genetic evaluation of residual feed intake adjusted for fat (RFIFat) is important for the appropriate use of feed efficiency in selection programs. The objective was to analyze the influence of selection for RFIF at on carcass and performance traits by estimating various genetic parameters. Data were analyzed from five tests of feed efficiency, which were conducted with 677 Nellore males. Genetic evaluation was performed by Bayesian inference using an animal model via single-and two-trait analyses. Variables analyzed were dry matter intake, average daily gain, RFIFat, rib eye area, back fat thickness, rump fat thickness, marbling score, and subcutaneous fat thickness. The posterior mean distributions estimated at each analysis were used to estimate heritability of the traits and to perform various correlations. The studied traits showed high heritability estimates, and they should respond well to selection. The RFIFat presented a phenotypic correlation with carcass traits (which was next to zero), and there was also a negative genetic correlation. Additive genetic variability for RFIFat showed that selection for this trait can promote genetic gains in future generations, resulting in animals that are efficient in terms of nutrient use, and according to the genetic and phenotypic correlations, with no significant negative changes to carcass traits.
\end{abstract}

Key words: back fat thickness, feed efficiency, genetic correlation, heritability.

Análise genética do consumo alimentar residual ajustado para gordura e de características de carcaça e desempenho em um rebanho Nelore

RESUMO: $O$ estudo da avaliação genética do consumo alimentar residual ajustado para a gordura (CARFat) é importante para o uso apropriado da eficiência alimentar em programas de seleção. Objetivou-se analisar a influência da seleção para CARFat sobre características de carcaça e de desempenho, frente à estimação dos parâmetros genéticos. Foram analisados os dados de cinco provas de eficiência alimentar, com 677 machos Nelore. A avaliação genética foi realizada por Inferência Bayesiana, com modelo animal, em análises uni e bicaracteristica. Foram analisadas as variáveis: ingestão de matéria seca, ganho de peso diário, CARFat, área de olho de lombo, espessura de gordura, espessura de gordura subcutânea na picanha, marmoreio e acabamento. As médias das distribuições a posteriori, estimadas em cada uma das análises, foram usadas para a estimação das herdabilidades e das correlações. As características estudadas apresentaram altas estimativas de herdabilidades, devendo responder bem à seleção. O CARFat apresentou correlações fenotípicas próximas a zero com as características de carcaça, e correlações genéticas negativas. A variabilidade genética aditiva observada para CARFat demonstra que a seleção para essa característica poderá promover ganhos genéticos nas futuras gerações, obtendo animais eficientes na utilização de alimentos e, de acordo com as correlações genéticas e fenotípicas encontradas, sem mudanças negativas significativas às características da carcaça.

Palavras-chave: espessura de gordura, eficiência alimentar, correlação genética, herdabilidade.

\section{INTRODUCTION}

Profitability of cattle breeding is strongly dependent on the spending of nutritional inputs, particularly given that there is a high share of food costs embedded in the total operating costs of production for different types of production systems. Therefore, food is one of the biggest expenses (LANCASTER et al., 2009) and; consequently, there are searches underway for more efficient animals in terms of nutrient use to help reduce the costs of production. Genetic selection for residual feed intake (RFI) has been used as a tool to increase the herd's feed efficiency without increasing the animal's maintenance requirements (LIMA et al., 2013).

It is important to ensure that selection by RFI does not have an adverse impact on the final product quality. Some studies reported that RFI 
is linked with the fat deposition rate, stating that animals with favorable phenotypes of RFI have leaner carcasses (NKRUMAH et al., 2007), which can lead to unwanted changes in carcass quality (ARTHUR et al., 2005). Therefore, adjusting fat when calculating the predicted consumption is an alternative method that can be used to reduce the possible deleterious effects of selection for feed efficiency. In this context, the objective of the present study was to analyze the influence of selection for RFI adjusted for fat (RFIFat) on carcass and performance traits by estimating the genetic parameters in a Nellore herd.

\section{MATERIALS AND METHODS}

Data were analyzed from five feed efficiency tests conducted from 2011-2014, with 677 uncastrated Nellore males; this study was performed at the Matinha Ranch Farm, Uberaba - MG, Brazil. A total of 15 days each were dedicated to diet and installation adaptation, and each test lasted an average of 74 days. A mean of 135 animals attended each test. The dry matter intake (DMI), average daily gain (ADG) intake, RFIFat, rib eye area (REA), back fat thickness (BFT), rump fat thickness (RFT), marbling score (MAR), and subcutaneous fat thickness (SFT) were evaluated. Data were pre-analyzed using the SAS program (2009); the data were consistent, requiring only the addition of animal age at the beginning of the test as a covariate.

Consumption was measured using the Growsafe $^{\circledR}$ system; troughs were always kept supplied with food, ensuring ad libitum consumption and unrestricted access to water. The diet was offered twice a day and $78 \%$ consisted of dry matter. In all tests, diets were formulated by isocaloric and isoproteic content, which represented around $70 \%$ of total digestible nutrients and $13 \%$ of crude protein. The animals were weighed on a calibrated digital balance, which was coupled to a cattle crush, at the beginning and end of the tests, and every 2 weeks during testing. At the beginning of the test, the animals had a mean \pm standard deviation age of $309 \pm 35$ days and they weighed $316 \pm 47 \mathrm{~kg}$.

Carcass traits were measured on the last day of each test by in vivo carcass ultrasound exam, with ultrasound pulses in frequencies ranging from 3-3.5 MHz, performed by a professional accredited by the Ultrasound Guidelines Council (UGC). For the collection of images, vegetable oil was used to ensure acoustic contact between the ultrasound device and the animal body. The REA was evaluated as a cross-sectional area of the Longissimus dorsi muscle between the $12^{\text {th }}$ and $13^{\text {th }}$ ribs. The BFT was evaluated as the thickness of subcutaneous fat deposits between the $12^{\text {th }}$ and $13^{\text {th }}$ ribs on the Longissimus dorsi muscle, and RFT was evaluated as the thickness of subcutaneous fat deposits between the ileum and ischiopubic bone, measured at the articulation point of the Gluteus medius and Biceps femoris. The MAR was evaluated as the percentage of intramuscular fat measured in the longitudinal direction on the Longissimus dorsi muscle between the $12^{\text {th }}$ and $13^{\text {th }}$ ribs. The SFT was calculated as 0.35 $\mathrm{BFT}+0.65$ RFT.

The kinship matrix used in the analysis was developed from animal pedigree information evaluated during the feed efficiency test at the Matinha Ranch Farm, provided by the Brazilian Association of Zebu Breeders (ABCZ), which featured a database of 3,741 animals. A recursive algorithm was used to maintain a set of pedigrees that was formed using data from animals and their ancestors. The ADG was calculated based on weight measurements. RFIFat is the difference between the observed and expected consumption, calculated by the regression between observed consumption, average metabolic weight, ADG, and SFT.

The genetic evaluation was performed using Bayesian analysis with an animal model in uni- and two-trait analyses using the GIBBS1F90 software; the posteriori estimates were obtained using the POSTGIBBS1F90 application (MISZTAL et al., 2014). The general model used is represented in matrix notation, as follows: $Y=X \beta+Z a+e$ , where $Y$ is a vector for $n$ observations; $\beta$ is the vector for fixed effects (feed efficiency test and animal age at the beginning of the test as a linear effect); $a$ is the vector of additive direct genetic effects; $e$ is the vector of the residual effect; and $X$ and $Z$ are the incidence matrices related to $\beta$ and $a$, respectively. In the uni- and two-trait analyses, it was considered that $E(Y)=X \beta$, while in the twotrait analyses it was assumed that $\operatorname{Var}(a)=A \otimes \Sigma_{a}$ and $\operatorname{Var}(e)=\operatorname{In} \otimes \sum_{e}$, and in the univariate analysis it was assumed that $E(\alpha)=0, E(e)=0$, where: $\Sigma_{a}$ is the additive genetic covariance matrix, $\Sigma_{e}$ is the residual covariance matrix, $A$ is the kinship matrix, $I$ is the identity matrix, $n$ is the number of registered animals, $\otimes$ denotes the direct product of matrices, $E(Y)$ is the expected estimator, $E(\alpha)$ is the expected predictor, and $E(e)$ is the expected error. Vectors $a$ and $e$ were considered to be independent. In the analysis using the Bayesian approach, vectors $\beta$ and $a$ are location parameters of a conditional distribution, $Y \mid \beta, a$. $\beta$ has a uniform distribution, 
reflecting vague a priori knowledge of this vector. Thus, the distribution of $\mathrm{Y}$, given the location parameters and scale, was considered: $Y \mid \beta, a, R \sim \mathrm{N}$ $[X \beta+Z a+I R]$.

Samples of the posterior distributions of the variance were generated from 500,000 cycles; of these, the first 40,000 were discarded, and the samples were stored at every 100th cycle. Convergence was checked via graphic inspection and sampled values were compared against interactions, as per the criterion proposed by GEWEKE (1992). This criterion was estimated using the Bayesian Output Analysis (BOA) statistical package from the R program (R CORE TEAM, 2015).

\section{RESULTS AND DISCUSSION}

The amplitude of the high probability density region (HPD), the variances (Table 1), and the heritability estimates (Table 2) demonstrated that all the studied traits were able to rightly respond to the selection process. Some studies (ALMEIDA et al., 2004; GOMES et al., 2012; GRION et al., 2014) estimated the phenotypic variation (standard deviation) for RFI in Nellore cattle, ranged from $0.41-1.05 \mathrm{kgday}^{-1}$, as was reported in this study for RFIFat (0.53). The phenotypic mean variances of ADG and DMI (Table 1) corroborate the findings of GRION et al. (2014), who studied Nellore cattle. The additive genetic variance of carcass traits showed high values in association with broad HPD. The HPD is a measure that provides a numeric range that includes $95 \%$ of the samples and their data or their estimates (SANTANA et al., 2014).
In a meta-analysis of 22 studies performed with various cattle breeds, DEL CLARO et al. (2012) estimated an RFI $h^{2}$ of $0.25 \pm 0.008$ (mean \pm standard error). Conversely, BERRY and CROWLEY (2012) estimated an RFI $h^{2}$ of $0.45 \pm 0.06$ (mean \pm standard error), which was closest to the mean \pm standard deviation for RFIFat in this study $(0.44 \pm 0.0059)$, despite the fact that they worked with taurine animals. This similarity may be due to the fact that European cattle breeds have high levels of fat depositions and high genetic variability for this trait. The DMI in studies by GRION et al. (2014), which were also performed with Nellore cattle, presented with higher $\mathrm{h}^{2}$ values, but for ADG, the $\mathrm{h}^{2}$ estimate was lower than that reported in this study. In the studied population, $\mathrm{h}^{2}$ estimates for REA, BFT, and RFT (mean \pm standard error) were higher than those reported by CAETANO et al. (2013) $(0.34 \pm 0.02,0.23 \pm 0.02$, and $0.31 \pm 0.02$, respectively) and than those mean \pm standard deviaton reported by SANTANA et al. (2014) $(0.35 \pm 0.14$, $0.21 \pm 0.08$, and $0.38 \pm 0.16$, respectively), who also worked with Nellore cattle. According to YOKOO et al. (2008), the REA is a determinant of carcass and meat cut quality, the BFT influences meat quality by protecting the carcass during the cooling process, and the RFT is an interesting trait for animals that were raised on pasture, because fat deposition begins earlier in the rump than the deposition of BFT.

The phenotypic correlation between RFIFat and ADG was close to zero (with an HPD of -0.41 at 0.67 ) (Figure 1), as was also reported by MAO et al. (2014) with Angus and Charolais animals, reaffirming the fact that the RFI is an independent measure of weight gain. The genetic

Table 1 - Means and standard deviations (SD) of the variables evaluated in the Nellore herd and their additive genetic $\left(\sigma_{a}^{2}\right)$, phenotypic $\left(\sigma_{P}^{2}\right)$, and residual $\left(\sigma_{R}^{2}\right)$ variance, in association with their high probability density region (HPD) and standard deviation (SD).

\begin{tabular}{|c|c|c|c|c|c|c|c|c|c|c|}
\hline \multirow{2}{*}{ Traits } & \multirow{2}{*}{ Mean \pm SD } & \multicolumn{3}{|c|}{ - } & \multicolumn{3}{|c|}{-} & \multicolumn{3}{|c|}{-} \\
\hline & & Mean & HPD & SD & Mean & HPD & SD & Mean & HPD & SD \\
\hline RFIFat & $0.0009 \pm 0.53$ & 0.14 & $0.05-0.24$ & 0.0022 & 0.17 & $0.10-0.24$ & 0.0014 & 0.32 & $0.27-0.36$ & 0.0008 \\
\hline $\mathrm{ADG}$ & $1.03 \pm 0.25$ & 0.35 & $0.15-0.58$ & 0.0045 & 0.34 & $0,18-0.48$ & 0.0029 & 0.69 & $0.59-0.80$ & 0.0016 \\
\hline DMI & $7.59 \pm 1.46$ & 0.26 & $0.08-0.44$ & 0.0041 & 0.44 & $0.31-0.56$ & 0.0027 & 0.70 & $0.61-0.80$ & 0.0015 \\
\hline REA & $65.78 \pm 9.62$ & 26.70 & $12.15-41.80$ & 0.2626 & 30.57 & $19.65-41.00$ & 0.1727 & 57.27 & $49.87-65.50$ & 0.0031 \\
\hline BFT & $4.04 \pm 1.35$ & 0.82 & $0.33-1.37$ & 0.0111 & 0.94 & $0.55-1.28$ & 0.0072 & 1.75 & $1.50-2.02$ & 0.0042 \\
\hline RFT & $5.07 \pm 1.26$ & 0.94 & $0.41-1.51$ & 0.0112 & 0.85 & $0.46-1.21$ & 0.0071 & 1.79 & $1.53-2.06$ & 0.0043 \\
\hline SFT & $4.71 \pm 1.26$ & 0.73 & $0.32-1.16$ & 0.0083 & 0.69 & $0.37-0.95$ & 0.0052 & 1.42 & $1.23-1.64$ & 0.0032 \\
\hline MAR & $1.95 \pm 0.47$ & 0.20 & $0.08-0.31$ & 0.0023 & 0.06 & $0.00-0.14$ & 0.0016 & 0.26 & $0.20-0.33$ & 0.0008 \\
\hline
\end{tabular}

RFIFat $=$ Residual feed intake adjusted for fat $(\mathrm{kg} /$ day $), A D G=$ average daily gain $(\mathrm{kg} /$ day $), \mathrm{DMI}=$ dry matter intake $\left(\mathrm{kgday}{ }^{-1}\right), \mathrm{REA}=\mathrm{rib}^{\mathrm{i}}$ eye area $\left(\mathrm{cm}^{2}\right)$, BFT $=$ back fat thickness $(\mathrm{mm})$, RFT $=$ rump fat thickness $(\mathrm{mm})$, SFT $=$ subcutaneous fat thickness, MAR $=$ marbling score $(\%), \mathrm{HPD}=$ high probability density region with $95 \%$ of samples. 
Table 2 - Mean, median, and mode of the heritability estimates $\left(\mathrm{h}^{2}\right)$ of the variables evaluated and their high probability density region (HPD) and standard deviations (SD).

\begin{tabular}{|c|c|c|c|c|c|}
\hline Traits & ------ & $-h^{2}$ & -------------------- & HPD & SD \\
\hline & Mean & Median & Mode & & \\
\hline RFIFat & 0.4429 & 0.4360 & 0.3742 & $0.1914-0.6980$ & 0.0059 \\
\hline ADG & 0.4991 & 0.4918 & 0.3564 & $0.2521-0.7563$ & 0.0053 \\
\hline DMI & 0.3677 & 0.3590 & 0.2500 & $0.1610-0.5979$ & 0.0051 \\
\hline REA & 0.4612 & 0.4541 & 0.4282 & $0.2487-0.6827$ & 0.0038 \\
\hline BFT & 0.4582 & 0.4491 & 0.6288 & $0.2204-0.7148$ & 0.0052 \\
\hline RFT & 0.5195 & 0.5123 & 0.3567 & $0.2803-0.7739$ & 0.0050 \\
\hline SFT & 0.5079 & 0.5003 & 0.5074 & $0.2720-0.7507$ & 0.0047 \\
\hline MAR & 0.7575 & 0.7927 & 0.5000 & $0.4190-1.0000$ & 0.0073 \\
\hline
\end{tabular}

RFIFat $=$ residual feed intake adjusted for fat $\left(\mathrm{kg}\right.$ day $\left.^{-1}\right), \mathrm{ADG}=$ average daily gain $\left(\mathrm{kgday}^{-1}\right), \mathrm{DMI}=\mathrm{dry}_{\text {matter intake }}\left(\mathrm{kg}\right.$ day $\left.{ }^{-1}\right), \mathrm{REA}=$ rib eye area $\left(\mathrm{cm}^{2}\right)$, BFT $=$ back fat thickness $(\mathrm{mm})$, RFT $=$ rump fat thickness $(\mathrm{mm})$, SFT $=$ subcutaneous fat thickness, MAR $=$ marbling score $(\%), \mathrm{HPD}=$ high probability density region with $95 \%$ of samples.

correlation between RFIFat and ADG was positive (0.13, with an HPD of -0.11 at 0.09 ) (Figure 1), which is in agreement with the findings of some studies (NKRUMAH et al, 2007; CROWLEY et al., 2010); however, ARTHUR et al. (2001) reported that these correlations are negative or equal to zero. The RFIFat is calculated based on phenotypic regressions of the production traits (observed consumption, average metabolic weight, $\mathrm{ADG}$, and SFT) and it is not genetically independent of the component traits; the sign and magnitude of the genetic correlations are influenced by both genetic and environmental factors associated with food consumption.

The RFIFat showed strong and positive phenotypic (0.65, with an HPD of 0.48 at 0.94$)$ and genetic correlations $(0.75$, with an HPD of 0.59 at 0.70$)$ with the DMI as was reported by MAO et al. (2014) with RFI ( 0.58 and 0.75 , respectively). This result was expected since the RFIFat represents the relationship between actual and predicted consumption. This genetic correlation is highly favorable, indicating that the less efficient animals (those with a positive RFIFat) are those that consume more dry matter and achieve the same weight gain, since the RFIFat is independent of ADG. Therefore, the RFIFat, which presents a high estimate of $h^{2}$ (Table 2), can be used as a criterion for the selection of feed efficiency, following the determination of animal traits or characteristics most important for each herd under selection according to the market to be reached.

BASARAB et al. (2003) and NKRUMAH et al. (2007) reported positive phenotypic correlations between RFI and carcass fat deposition that ranged from 0.14 to 0.30 , and negative phenotypic correlations between RFI and muscle deposition ranging from -0.21 to -0.14 , stating that with respect to the RFI, the less efficient animals have greater fat deposition. In the studied Nellore herd, the RFIFat presented a phenotypic correlation that was next to zero for the studied carcass traits (Figure 1). Genetic correlations between RFIFat and carcass traits were negative, but they were associated with broad HPD, likely due to the small number of animals studied. Phenotypic and genetic correlations between carcass traits and RFIFat close to zero suggest that the selection for RFIFat will have insignificant effects on carcass quality.

By including adjustments for BFT in the RFI model, as conducted by MAO et al. (2014), there was an apparent reduction in the phenotypic correlation between RFI and BFT that decreased from 0.19 to 0.01 for Charolais steers and from 0.07 to 0.02 for Angus breed animals; there was also a reduction in the magnitude of the genetic correlation between RFI and BFT (0.42 to 0.23) and between RFI and MAR (0.14 to 0.02) in the Charolais steers, as well as a slight reduction in the genetic correlation with MAR in Angus steers (0.18 to 0.15$)$. As was reportec in this study, the literature demonstrated that the phenotypic correlation between RFI and REA is low or even nil (BASARAB et al., 2003; NKRUMAH et al., 2007; LANCASTER et al., 2009), suggesting that adjusting for this trait would be of little use. Adjusting the RFI in the model will lead to a measure that is independent of the phenotypic trait that was adjusted.

The results reported in this research, in association with the findings in the literature, 


\begin{tabular}{|l|r|r|r|r|r|r|}
\hline & \\
\end{tabular}

suggested that by adjusting for fat in the RFI model, it will be possible to mitigate the negative impact of the selection of more feed efficient animals on carcass traits. Genetic and phenotypic analyses of RFI and their interpretations should be performed while bearing in mind the studied breed and the market demands that the herd intends to serve.

\section{CONCLUSION}

Genetic variability in RFIFat demonstrated that selecting for this trait can promote genetic gains, resulting in efficient food use animals. According to the genetic and phenotypic correlations, these animals will not exhibit significant negative changes in carcass traits.

\section{ACKNOWLEDGEMENTS}

Dr. Luciano Ribeiro (Matinha Ranch Farm) for providing the data. Coordenação de Aperfeiçoamento de Pessoal de Nível Superior (CAPES) for providing financial support. English-language editing of this manuscript was provided by Journal Prep. Dr. Ignacy Misztal and collaborators for providing free access to the RENUMF90, GIBBS1F90, and POSTGIBBSF90 software programs.

\section{REFERENCES}

ALMEIDA, R., et al. Consumo alimentar residual: um novo parâmetro para avaliar a eficiência alimentar de bovinos de corte. In: REUNIÃO ANUAL DA SOCIEDADE BRASILEIRA DE ZOOTECNIA, 41., 2004, Campo Grande - MS. Anais... SBZ, 2004. p.03-14.

ARTHUR, P.F. et al. Maternal productivity of Angus cows divergently selected for post-weaning residual feed intake. Australian Journal of Experimental Agriculture, v.45, n.8, p.985-993, 2005. Available from: <http://www.publish.csiro.au/ paper/EA05052.htm>. Accessed: Sept. 22, 2015. doi: 10.1071.

ARTHUR, P.F. et al. Genetic and phenotypic variance and covariance components for feed intake, feed efficiency and other postweaning traits in Angus cattle. Journal of Animal Science, v.79, n.11, p.2805-2811, 2001. Available from: <https://www.animalsciencepublications.org/publications/ jas/articles/79/11/2805>. Accessed: Aug. 29, 2015. doi: 2001.79112805 .

BASARAB, J.A. et al. Residual feed intake and body composition in young growing cattle. Canadian Journal of Animal Science, v.8, n.2, p.189-204, 2003. Available from: <http://www. nrcresearchpress.com/doi/pdf/10.4141/A02-065>. Accessed: Sept. 12, 2015. doi: 10.4141/A02-065.

BERRY, D.P.; CROWLEY, J.J. Residual intake and body weight gain: anew measure of efficiency in growing cattle. Journal of Animal 
Science, v.90, n.1, p.109-115, 2012. Available from: <https://www. animalsciencepublications.org/publications/jas/articles/90/1/109>. Accessed: Sept. 23, 2015. doi: 10.2527/jas.2011-4245.

CAETANO, S.L. et al. Estimates of genetic parameters for carcass, growth and reproductive traits in Nellore cattle. Livestock Science, v.155, n.1, p.1-7, 2013. Available from: <http://www.sciencedirect. com/science/article/pii/S1871141313001686>. Accessed: Oct. 13, 2015. doi: 10.1016/j.livsci.2013.04.004.

CROWLEY, J.J. et al. Phenotypic and genetic parameters for different measures of feed efficiency in different breeds of Irish performance-tested beef bulls. Journal of Animal Science, v.88, n.3, p.885-894, 2010. Available from: <https://www. animalsciencepublications.org/publications/jas/articles/88/3/885>. Accessed: Sept. 02, 2015. doi: 10.2527/jas.2009-1852.

DEL CLARO, A. C. et al. Metaanalysis of genetic parameter estimates of residual feed intake and of its component traits in cattle. Pesquisa Agropecuária Brasileira, v.47, n.2, p.302-310, 2012. Available from: $<$ http://www.scielo.br/scielo.php?script=sci arttext\&pid=S0100-204X2012000200020>. Accessed: Sept. 05, 2015. doi: 10.1590 .

GEWEKE, J. Evaluating the accuracy of sampling-based approaches to the calculation of posterior moments. Bayesian Statistical, v.4, n.1, p.169-193, 1992. Available from: <http:// citeseerx.ist.psu.edu/viewdoc/download;jsessionid=BD177452F6 2A09165FA87C5498747CC7?doi=10.1.1.27.2952\&rep=rep1\&ty pe $=$ pdf $>$. Accessed: Aug. 17, 2015.

GOMES, R.C. et al. Protein synthesis and degradation gene SNPs related to feed intake, feed efficiency, growth, andultrasoundcarcasstraitsin Nellorecattle. Genetic and Molecular Research, v.12, n.3 p.2923-2936,2013. Available from: $<$ http://www.geneticsmr.com//year2013/vol12-3/pdf/gmr2593. pdf $>$. Accessed: Aug.17, 2015.

GRION, M.E.Z. et al. Selection for feed efficiency traits and correlated genetic responses in feed intake and weight gain of Nellore cattle. Journal of Animal Science, v.92, n.3, p.955-965, 2014. Available from: <https://www.animalsciencepublications. org/publications/jas/articles/92/3/955>. Accessed: Aug. 28, 2015. doi: $10.2527 /$ jas.2013-6682.

LANCASTER, P.A. et al. Phenotypic and genetic relationship of residual feed intake with performance and ultrasound carcass traits in Brangus heifers. Journal of Animal Science, v.87, n. 12, p.3887-3896,
2009. Available from: $<$ https://www.animalsciencepublications.org/ publications/jas/articles/87/12/3887>. Accessed: Sept. 11, 2015. doi: $10.2527 /$ jas.2009-2041.

LIMA, N.L.L. et al. Consumo alimentar residual como critério de seleção para eficiência alimentar. Acta Veterinária Brasilica, v.7, n.4, p.255-260, 2013. Available from: <http://periodicos.ufersa. edu.br/revistas/index.php/acta/article/view/3269>. Accessed: Jun. 29, 2015. ISSN 1981-5484.

MAO, F. et al. Phenotypic and genetic relationships of feed efficiency with growth performance, ultrasound, and carcass merit traits in Angus and Charolais steers. Journal of Animal Science, v.91, n.5, p.2067-2076, 2013. Available from: <https://www. animalsciencepublications.org/publications/jas/articles/91/5/2067>. Accessed: Sept. 04, 2015. doi: 10.2527/jas.2012-5470.

MISZTAL, I. et al. Using recursion to compute the inverse of the genomic relationship matrix. Journal of Dairy Science,v.97, n.6, p.3943-3952, 2014. Available from: <http://www. journalofdairyscience.org/article/S0022-0302(14)00224-0/pdf $>$. Accessed: Oct. 29, 2015. doi: 10.3168/jds.2013-7752.

NKRUMAH, J.D. et al. Genetic and phenotypic relationships of feed intake and measures of efficiency with growth and carcass merit of beef cattle. Journal of Animal Science, v.85, n.10, p.2711-2720, 2007. Available from: <https://www.animalsciencepublications. org/publications/jas/articles/85/10/0852711>. Accessed: Sept. 22, 2015. doi: 10.2527/jas.2006-767.

R CORE TEAM. R: alanguage and environment for statistical computing. R Foundation for Statistical Computing. Vienna, Austria, 2015. Available from: <http://www.R-project.org/>. Accessed: Jun. 22, 2015.

SANTANA, M.H.A.et al. Genetic parameter estimates for feed efficiency and dry matter intake and their association with growth and carcass traits in Nellore cattle. Livestock Science, v.67, n.1, p.80-85, 2014. Available from: <http://www.sciencedirect.com/ science/article/pii/S1871141314003096>. Accessed: Oct. 21, 2015. doi: 10.1016/j.livsci.2014.06.002.

YOKOO, M.J. et al. Genetic and environmental factors affecting ultrasound measures of longissimus muscle area and backfat thickness in Nellore cattle. Livestock Science, v.117, n.2, p.147154, 2008. Available from: <http://www.sciencedirect.com/ science/article/pii/S1871141307005604>. Accessed: Sept. 29, 2015. doi: 10.1016/j.livsci.2007.12.006. 